\title{
Sex Determination by Observation of Barr Body in Teeth Subjected to High Temperatures
}

\author{
Determinación del Sexo Mediante la Observación de la \\ Cromatina de Barr en Piezas Sometidas a Altas Temperaturas
}

"Iván Suazo Galdames; *Alex Flores; "Ignacio Roa; ** Mario Cantín \& **,,*Daniela Zavando

SUAZO, G. I.; FLORES, A.; ROA, I.; CANTÍN, M. \& ZAVANDO, D. Sex determination by observation of Barr body in teeth subjected to high temperatures. Int. J. Morphol., 29(1):199-203, 2011.

SUMMARY: Sex determination is one of the keys in the identification process. A useful histological method for sex determination is the observation of Barr chromatin or Barr body. This study determines the effect of high temperatures on the diagnostic performance of the Barr chromatin observation on teeth. Were used 50 healthy teeth from 25 male and 25 female individuals aged between 14 and 44 years. The teeth were divided into 5 groups (each group with 5 female and 5 male teeth) and were exposed to controlled temperatures of 200, 400, 600, 800, and 1000 degrees C for 5 minutes. The coronal pulp was obtained and the tissue was processed and stained with hematoxylin-eosin. Four histological slides of male and 4 of female individuals were randomly selected, for each temperature level, which were observed by conventional microscopy at 100X magnification, each showing 50 cells per plate. The presence of 1 cell with visible sex chromatin was considered positive for females. It was only possible to evaluate the samples from groups subjected to 200 and 400 degrees $\mathrm{C}$. In the groups analyzed, the test showed $100 \%$ accuracy. The average number of cells found to be positive Barr chromatin was 15 (SD 3.9) at 200 degrees C and 11 (SD 2.8) at 400 degrees C. Hence, it was possible to detect the sex at these temperatures by observing chromatin of the Barr body in dental pulp.

KEY WORDS: Barr chromatin; Sex determination; Forensic dentistry.

\section{INTRODUCTION}

Natural disasters in areas of high population density, mass transportation accidents, development of military conflict and terrorism, among others, usually require a large number of individuals to be identified. The process is easy if the bodies are well preserved or documentation is enables forensic identification. However, when the victims are carbonized, dismembered, or have an advanced degree of tissue destruction, the process of establishing identity is difficult or impossible. The forensic identification process can be initiated by antemortem and postmortem records of previous history, or from a reconstructive expertise on biological remains, determining age, sex, biotype, height, and others (Melani, 1998).

As indicated, sex determination plays a key role; anthropological methods based on morphological characteristics of the bones (Krenzer, 2006; Suazo et al., 2008a, 2008b, 2008c; Suazo et al., 2009) and molecular methods based on analysis of nuclear or mitochondrial DNA (Iwamura et al., 2004) are described.

An intermediate histological method, which is useful for sex determination, is to observe the presence of sex chromatin or Barr chromatin in somatic cells (Vera et al., 1986) similar to those present in the pulp of the teeth or the osteon central canal. The method was designed by Barr \& Bertram (1949), when they analyzed nerve cells of cats in which noted that the cell nuclei of females had a high percentage of a dense mass of chromatin unlike males (Barr \& Carr, 1960; Pujol, 1992).

Recently, Suazo et al. (2010) generated a gold stan-

* Universidad de Talca, Chile.

** Universidad de La Frontera, Chile.

**** Facultad de Ciencias de la Salud, Universidad Autónoma de Chile, Sede Talca, Chile.

Funding: Project DIUTALCA VAC493 
dard from cells with sex chromatin in 50 cells per field of pulp samples of healthy human teeth, reporting $100 \%$ accuracy for this parameter, concluding that the histological observation of the pulp allows the sex diagnosis.

This finding is of importance because the teeth are protected by the oral tissues and the pulp and further by the mineralized constituents of the tooth. This allows the conservation and sustainable production of cell pulp to help sex determination in circumstances where other tissues cannot be analyzed.

Therefore, this study evaluated the in vitro effect of high temperatures on Barr chromatin on dental pulp, in the context of sex diagnosis. This study provides important data on the relevance and performance of this test to events that involve exposure to elevated temperatures, such as fire, in which other methods cannot be employed.

\section{MATERIAL AND METHOD}

Study design: An in vitro study of exposure to high temperatures was performed. Samples used, were 50 teeth from 25 female and 25 male patients; mean age for women was 23.07 years (SD: 1.84) and for men 25.88 years (SD: $3.85)$. Eligibility criteria included no previous history of systemic or dental disease; patients with sexual differentiation disorders were also not considered. The teeth should be healthy and an indication for removal would correspond to one of the following clinical situations: orthodontic indication, tooth extraction for prosthetic reasons (any tooth), and third molars with prophylactic indication were scored.

Either the patients or their guardians, if they are minors, were informed about the objectives of the investigation. They voluntarily donated their teeth, without any form of incentive.

Procedure. The teeth were removed by conventional technique, washed with sterile water to remove residual blood, and then placed in a sealed container with $10 \%$ formalin (labeled by age and sex), at a temperature of $34^{\circ} \mathrm{C}$ (room temperature) and relative humidity of $100 \%$.

Then, the teeth were carried in a metal box to an STYB dewaxing oven, model K955, and heated to 200, 400, 600,800 , and $1000{ }^{\circ} \mathrm{C}$. The 10 teeth $(5$ from male and 5 female individuals) were placed for five minutes at each temperature. Subsequently, the lid of the oven was opened, the box opened with a clamp, and taken to a work tray where it was cooled to room temperature. The coronal pulp of the teeth of each group was obtained by fracture, fixed in $10 \%$ formalin, and processed and stained with hematoxylin-eosin.

Serial cuts of $7 \mu \mathrm{m}$, which were selected by random sampling of 4 plates, were analyzed under a trinocular microscope Olympus CX21 $®$ at 100X magnification. The analysis procedure was previously described by Suazo et al. (2010), who systematically observed 50 cells per plate.

To consider a positive Barr chromatin test, one cell in the sheet had to form chromatin condensation at the nuclear periphery.

The use of contingency tables was made to determine the overall accuracy of the diagnostic method of observation of sex chromatin in dental pulps of teeth subjected to extreme heat. This further established the sensitivity of the method for the diagnosis of men and women at different temperatures.

\section{RESULTS}

It was only possible to process samples from groups subjected to 200,400 , and $600{ }^{\circ} \mathrm{C}$. At higher temperatures, the degree of calcination of the teeth did not allow the extraction of the pulp for histological processing.

Observation of Barr chromatin in the pulps of teeth subjected to $200{ }^{\circ} \mathrm{C}$

In a histological analysis of the male samples subjected to $200{ }^{\circ} \mathrm{C}$, connective tissue showed low cell density and a large number of disordered collagen fibers. The cells corresponded to fibroblast with hyperchromatic nuclei, in which there was no further condensation of chromatin in the nuclei (Fig. 1).

In the females, the fibroblasts, with oval nuclei, there was hyperchromatism, and the periphery showed a condensation of Barr chromatin with a variable number of cells, presence of fundamental substance, connective and vascular tissues, with disorganized collagen fibers (Fig. 2).

The overall accuracy of the method was $100 \%$. The sensitivity for men and women was $100 \%$, as there was no presence of Barr chromatin in male and female teeth.

In samples from females, of the 50 displayed, the average number of cells expressing Barr chromatin was 15 , with a DS of 3.9. 


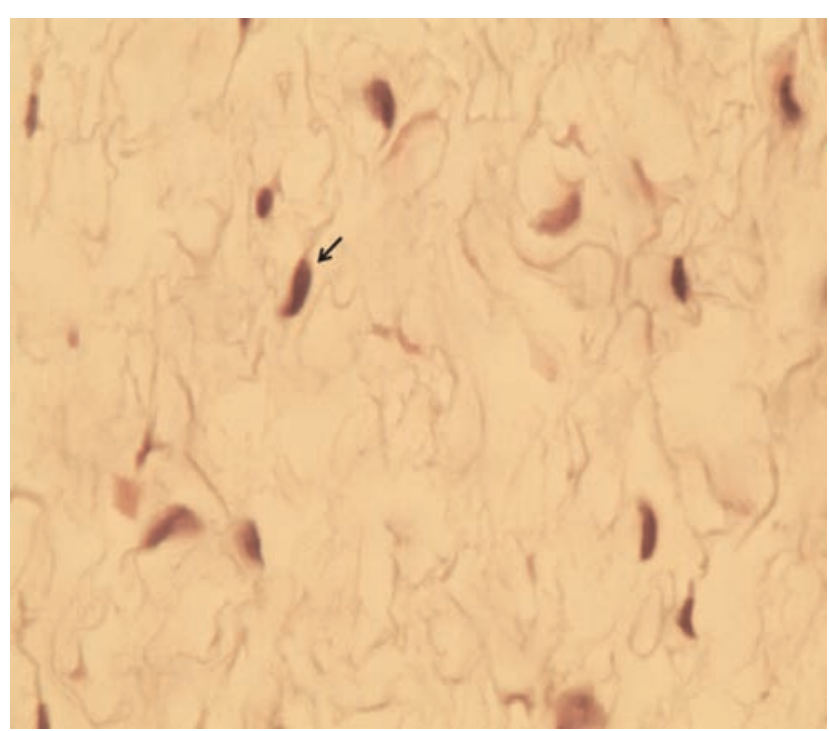

Fig. 1. Male pulp sample at $200{ }^{\circ} \mathrm{C}$ in $\mathrm{CX} 21$ trinocular microscope (Olympus ${ }^{\circledR}$ ). Magnification 100X.

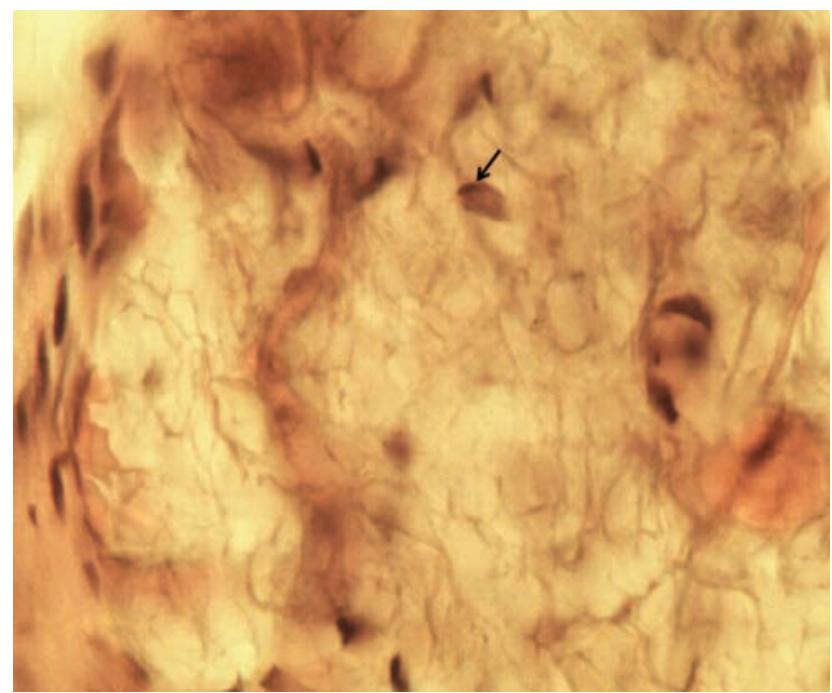

Fig. 2. Female pulp sample at $200{ }^{\circ} \mathrm{C}$ observed in CX21 trinocular microscope (Olympus $\left.{ }^{\circledR}\right)$. Magnification 100X.

Observation of Barr chromatin in the pulps of teeth subjected to $400{ }^{\circ} \mathrm{C}$.

By histological analysis of samples from males the connective tissue was observed to have a lower cell density than that observed at $200{ }^{\circ} \mathrm{C}$, collagen fibers were more disorganized, and fibroblasts lacked Barr chromatin (Fig.3).

The females also showed a lower cell density and a disorganized collagen matrix. The fibroblasts had nuclei staining affinity, and the outer areas contain hyperchromatic chromatin condensation of Barr chromatin (Fig. 4).

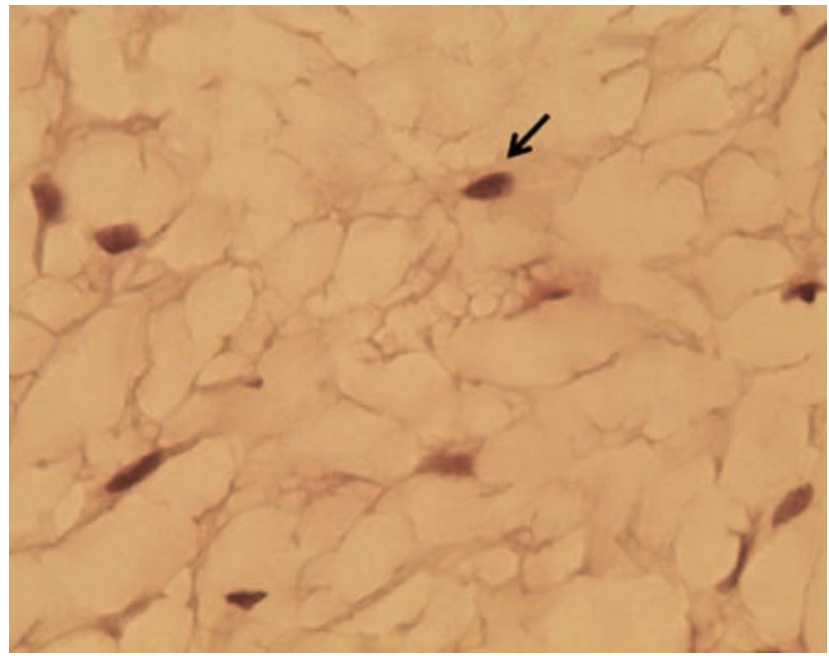

Fig. 3. Male pulp sample at $400^{\circ} \mathrm{C}$ observed in CX21 trinocular microscope (Olympus ${ }^{\circledR}$ ). Magnification 100X.

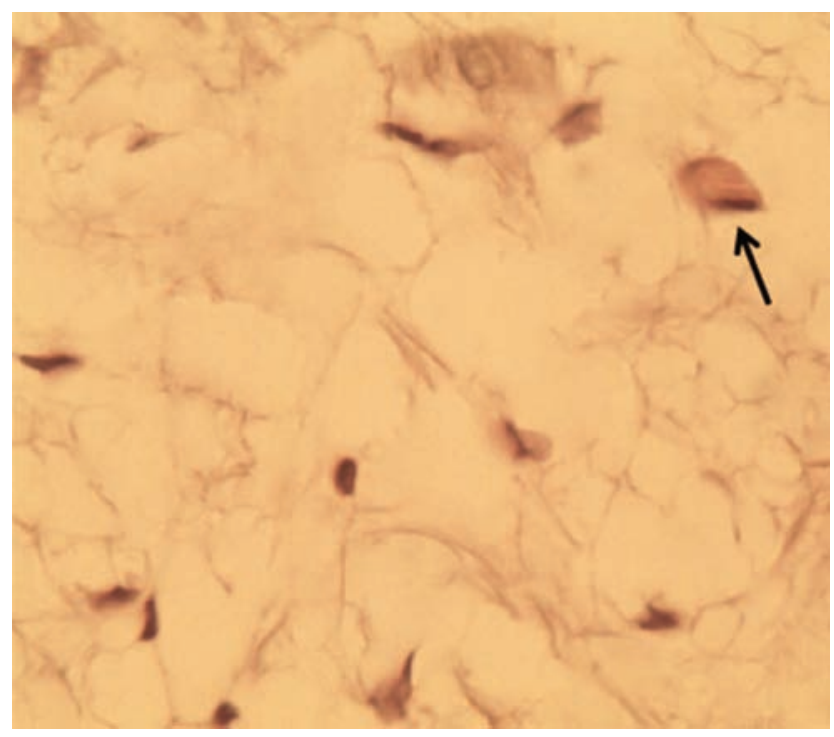

Fig. 4. Female pulp sample at $400^{\circ} \mathrm{C}$ observed in CX21 trinocular microscope (Olympus ${ }^{\circledR}$ ). Magnification 100X.

The overall accuracy of the method was $100 \%$. The sensitivity for men and women was $100 \%$, as there was no presence of Barr chromatin.

In female samples, of the 50 displayed, the average number of cells expressing Barr chromatin was 11, with a DS of 2.8 .

Observation of Barr chromatin in the pulps of teeth subjected to $600{ }^{\circ} \mathrm{C}$

In males, a mass of dark tissue, due to calcination was observed; no cell was present (Fig. 5). 


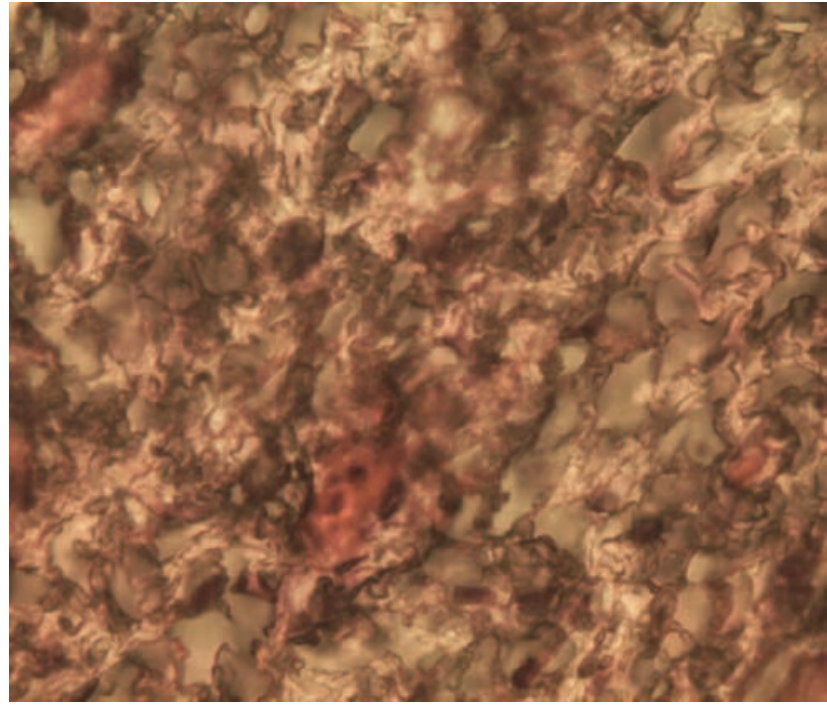

Fig. 5. Male pulp sample at $600^{\circ} \mathrm{C}$ observed in CX21 trinocular microscope (Olympus ®). Magnification 100X.

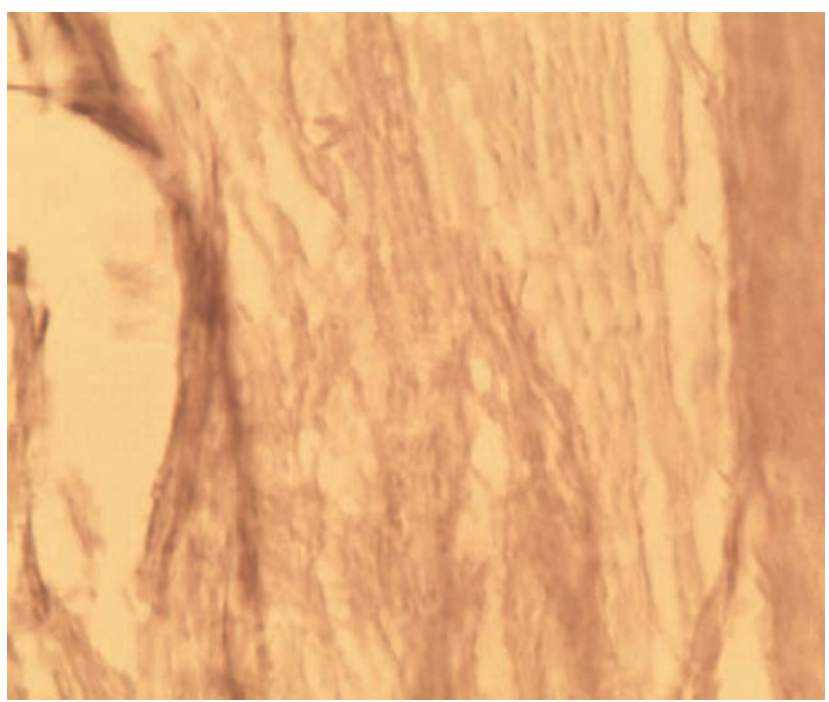

Fig. 6. Female pulp sample at $600^{\circ} \mathrm{C}$ observed in CX21 trinocular microscope (Olympus ®). Magnification 100X.

In females there was a mass of tissue in disarray, with collagen fibers cut and denatured, and no cells were observed. So, it was not possible to establish the presence of sex chromatin (Fig. 6).

\section{DISCUSSION}

Sex determination by sex chromatin (Barr chromatin or Barr body) observation is possible in parts subjected to temperatures of $400{ }^{\circ} \mathrm{C}$. At higher temperatures $\left(600{ }^{\circ} \mathrm{C}\right)$, the histological process is difficult and the tissue appeared disorganized. At $800{ }^{\circ} \mathrm{C}$ and $1000{ }^{\circ} \mathrm{C}$, it was not possible to find any viable tissue for analysis. At $200{ }^{\circ} \mathrm{C}$, this study showed values similar to those reported by Suazo et al. (2010), where $30 \%$ of the female pulp cells were positive for the test observation of Barr chromatin. These values are lower than those reported by Duz (2000), for whom $56.18 \%$ of the pulp cells express the female sex chromatin.

The percentage of Barr chromatin in the female pulp cells decreased to $22 \%$ when the sample was subjected to $400{ }^{\circ} \mathrm{C}$, suggesting that the increased temperature affects the diagnostic test, although in nonsignificant terms, as the overall accuracy of the method at this temperature also was $100 \%$. It is necessary to assess whether an increase in exposure time at temperatures above $200{ }^{\circ} \mathrm{C}$ decreases the accuracy of the diagnostic test.

Duz reported 1 to $3 \%$ of false positives, which differ from the results of the present study, as the presence of Barr chromatin was observed in all the males.

It is interesting to note that the experimental conditions in this study do not accurately represent the stage of identification of the subjects exposed to high temperatures from fire, explosion, etc. This study was carried out in vitro, where the temperature affected the teeth directly and uniformly. Metal boxes included leading and this increased the heat inside. This condition is very different from what occurs in an individual's mouth and teeth that are in the dental alveolus, protected by muscle tissue, bone, mucous, and remain isolated from the direct action of heat. Hence, the temperature that goes directly to the tooth is much lower than the external medium that causes the fire or the explosion. Moreover, the exposure time of a body in a fire is variable, so the time factor has yet to be investigated in the future.

This study provides relevant information about the diagnostic value of Barr's chromatin observation in healthy teeth subjected to high temperatures, but it is necessary to evaluate the performance of this test in different conditions, such as burial, salinity, $\mathrm{PH}$, and entitlement to forensic identification.

SUAZO, G. I.; FLORES, A.; ROA, I.; CANTÍN, M. \& ZAVANDO, D. Determinación del sexo mediante la observación de la cromatina de Barr en piezas sometidas a altas temperaturas. Int. J. Morphol., 29(1):199-203, 2011.

RESUMEN: La determinación del sexo es uno de los pilares del proceso de identificación, Un método histológico útil para la determinación del sexo es la observación de cromatina de 
Barr. El objetivo de este estudio fue determinar el efecto de altas temperaturas sobre el rendimiento diagnóstico de observación de cromatina de Barr en piezas dentarias. Se utilizaron 50 piezas dentarias sanas, 25 de individuos de sexo masculino y 25 de sexo femenino con edades comprendidas entre los 14 y 44 años. Las piezas dentarias fueron divididas en 5 grupos, (cada grupo con 5 piezas de sexo femenino y 5 de sexo masculino) y fueron expuestas a temperaturas controladas de $200^{\circ} \mathrm{C}, 400^{\circ} \mathrm{C}, 600^{\circ} \mathrm{C}, 800^{\circ} \mathrm{C}$ y $1000^{\circ} \mathrm{C}$ por 5 minutos. La pulpa coronaria fue obtenida y el tejido fue procesado para $\mathrm{H}-\mathrm{E}$. Se seleccionaron aleatoriamente 4 placas histológicas de individuos de sexo masculino y 4 de sexo femenino, por cada nivel de temperatura, las cuales fueron observadas por microscopía convencional a un aumento de 100X, observándose 50 células por placa. La presencia de 1 célula con cromatina sexual visible se consideró positiva para el sexo femenino. Sólo fue posible evaluar las muestras provenientes de los grupos sometidos a $200^{\circ} \mathrm{C}$ y $400^{\circ} \mathrm{C}$. En los grupos analizados la prueba presentó un $100 \%$ de exactitud. El número medio de células Barr positivas encontradas fue de $15(\mathrm{DS} 3,9)$ a $200^{\circ} \mathrm{C}$ y $11(\mathrm{DS} 2,8)$ a $400^{\circ} \mathrm{C}$, por lo que a estas temperaturas fue posible el diagnóstico del sexo mediante la observación de la cromatina sexual en pulpa dental.

PALABRAS CLAVE: Cromatina de Barr; Determinación del sexo; Odontología forense.

\section{REFERENCES}

Barr, M \& Carr, D. Sex chromatin, sex chromosomes and sex anomalies. Can. Med. Assoc. J., 83:979-86, 1960.

Barr, M. L. \& Bertram, E. G. A morphological distinction between neurones of the male and female, and the behaviour of the nucleolar satellite during accelerated nucleoprotein synthesis. Nature, 163:676, 1949.

Duz, S. A determinação do sexo através da cromatina sexual na pulpa dentaria e sua importância pericial. Tese para obtenção do grau de Mestre de Odontologia legal e Deontología. Piracicaba, SP, Universidade Estadual de Campinas, 2000.

Iwamura, M.; Soares, D. \& Romero, M. Human identification and analysis of DNA in bones. Rev. Hosp. Clin. Fac. Med. São Paulo, 59:383-8, 2004.

Krenzer, U. Compendio métodos antropológicos forenses para la reconstrucción del perfil ósteo-biológico: Métodos para la determinación del sexo. Guatemala, DED Guatemala, 2006.

Melani, H. R. Identificação humana em víctimas de carbonização: análise odonto-legal através da microscopía eletrônica. Tesis Doctoral Odontologia Le- gal y deontología. Piracicaba, SP, Universidad Estatal de Campinas, 1998.

Pujol, A. P. Sexo genético: práctica actual y limitaciones de su uso como screening de feminidad en los Juegos Olímpicos. Apunts. Medicina de l'Esport, 29:39-46, 1992.

Suazo, G. I. C.; Zavando, M. D. A. \& Smith, R. L. Sex determination using mastoid process measurements in Brazilian skulls. Int. J. Morphol., 26:941-4, 2008a.

Suazo, G. I. C.; Zavando, M. D. A \& Smith, R. L. Evaluating accuracy and precision in morphologic traits for sexual dimorphism in malnutrition human skull: a comparative study. Int. J. Morphol., 26:877-81, 2008b.

Suazo, G. I.; Cantín, L. M; López, F. B.; Sandoval, M. C.; Torres, M. S.; Gajardo, R. P. \& Gajardo, R. M. Sexual dimorphism in mesiodistal and bucolingual tooth dimensions in Chilean people. Int. J. Morphol., 26:609$14,2008 \mathrm{c}$.

Suazo, G. I. C.; Zavando, M. D. A. \& Smith, R. L. Sex determination in mandibles in the first year of life by a quantitative approach. Int. J. Morphol., 27:113-6, 2009.

Suazo, G. I.; Roa, H. I. \& Cantín, L. M. Sex chromatin in dental pulp. Performance of diagnosis test and gold standard generation. Int. J. Morphol., 28:1093-6, 2010.

Vera, D.; Youlton, R. \& Cecilia, B. Cromatina de Barr: Análisis de su valor actual. Rev. Chil. Pediatr., 57:506-9, 1986.

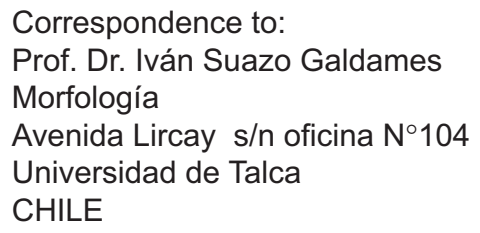

Phone: 56-71-201682

Email: isuazo@utalca.cl

Received: 23-12-2010

Aceptado: 12-01-2011 